\title{
Risk Assessment of Mercury Exposure in The Gold Processing Community in Krueng Kalee Village, South Aceh
}

\author{
Rizki Srimaulia Hartati ${ }^{1}$ \\ Department of Environmental Health \\ Faculty of Public Health, University of Sumatera Utara \\ Medan, Indonesia \\ rizkisrimaulia@gmail.com
}

\author{
Nurmaini ${ }^{2}$, Taufik Ashar ${ }^{3}$ \\ Department of Environmental Health \\ Faculty of Public Health, University of Sumatera Utara \\ Medan, Indonesia \\ nurmainik@yahoo.com \\ doctta@gmail.com
}

\begin{abstract}
Gold processing activities of artisanal gold mining at Krueng Kalee Village is using a method called amalgamation. Amalgamation method is a process of binding the gold metal from gold ore by using mercury in a tromol tube. The waste from the amalgamation process is released directly to the environment without any waste processing and caused contamination to the well water. This study aimed to determine the level of risk to mercury at Krueng Kalee community through health risk assessment approach. This study using purposive sampling as sampling method. Measurements were made by measuring the mercury concentration in the well water and anthropometry measurement community is weight. The default factor value is applied to the calculation of the exposure frequency. Non carcinogenic health risks are expressed by Risk Quotients which is obtained by divinding the intake with reference dose. The result showed that the mean concentration of mercury in the well water is $0,0032 \mathrm{mg} / \mathrm{L}$ which means that the concentration of mercury in the respondent's well water has exceed the regulatory of health minister on water requirement where the mercury maximum allowable level in drinking water is $0,0001 \mathrm{mg} / \mathrm{L}$. Value of Risk Quotients is greater than 1 which means that the Krueng Kalee community are at risk of non carcinogenic health disorders and assuming that mercury exposure comes from only contaminated well water and do not take to account mercury exposure from other sources .
\end{abstract}

Keywords- Exposure Assessment; Water; Risk Quotient; Non Carcinogenic

\section{INTRODUCTION}

Mercury (with the chemical symbol of $\mathrm{Hg}$ ) is a naturally occurring element found in air, water, and soil. It is distributed throughout the environment by both natural process and anthropogenic (human) activities. Mercury is found in various inorganic and organic forms and is persistent in the environment. Since the start of the industrial age (e.g., mining, burning of fossil fuels) human activities have resulted in additional release of mercury to the environment [1]. Industrial exhausts such as heavy metals can be accumulated and toxic to living things. Included in this category is tailings which is a finely ground rock to remove gold in a gold mining process [2]. Tailings waste is the result of a gold amalgamation process. Amalgamation is the process of applying gold particles by mercury and forming a mercurymetal solid solution [3]. Globally, artisanal and small-scale gold mining is the largest source of mercury emissions (37\%), followed by coal combustion $(24 \%)$. Other major emission sources are non-ferrous metal production and cement production [4]. The large number of artisanal gold mining in South Aceh has increased mercury contamination through the extraction of gold.

The primary targets for toxicity of mercury and mercury compounds are the nervous system, the kidneys, and the cardiovascular system. It is generally accepted that developing organ systems (such as the fetal nervous system) are the most sensitive to toxic effects of mercury. Fetal brain mercury levels appear to be significantly higher than in maternal blood and the developing central nervous system of the fetus is currently regarded as the main system of concern as it demonstrates the greatest sensitivity. Other systems that may be affected include the respiratory, gastrointestinal, hematologic, immune, and reproductive systems [5].

The most well known case of mercury contamination is the case that occurred in Minamata Bay, Japan. It was found that 19 babies born deformed with symptoms of mental retardation as well as arms and legs became inferred spastic transferred from the mother through the placenta during pregnancy. The disease is then called Minamata disease [6].

Public Health Assessment (PHA) approach can used to assess the impact of mercury contamination into the environment. Public Health Assessment is defined as "The evaluation of data and information on the release of hazardous substances into the environment in order to assess any (past), current, or future impact on public health, develop health advisories or other recommendations, and identify studies or actions needed to evaluate and mitigate or prevent human health effects". The two models used in this PHA are Environmental Health Risk Assessment and Environmental Health Epidemiology [7]. WHO (1983) stated that an environmental health risk assessment is still rarely used in the environmental impact assessment of public health. Most analyzes are done conservatively with epidemiological studies. Indeed, for centuries epidemiological studies have been the 
method of investigating infectious diseases in the community [8].

Several studies was conducted to assess health risks from mercury exposure. Non-cancer health hazard (risk) that faced by artisanal mine workers from exposure to $\mathrm{Hg}$ via oral ingestion water from rivers in Ghana with reasonable maximum exposure generate Hazard Quotient value 4,50 higher than the USEPA guidance value [9]. There is a research that observed the mercury contamination at Makassar, Indonesia, found that fisherman who live in coastal area of Makassar City have high risk (RQ>1) to exposure to mercury at the place where the gold is sold and the process (gild) has a substantial contribution to the increased pollution of mercury in the coastal region of Makassar City [10]. On the other hand, risk factors that affect mercury concentration on the respondent is working status, location, length of stay, status of miner and the working hours of amalgam burners. These risk factors account for $45.8 \%$ of the accumulated mercury in the hair of the respondent's head [11].

Krueng Kalee village is one of the gold mining area in Aceh with 50 dots of gold mining location around the society settlement. They are using mercury almost $1-1,5 \mathrm{~L}$ in a day and the tailings waste was thrown away with any waste processing and it has caused mercury contamination to the environment. If the contained waste of gold processing contaminate the environment, especially water, it will give several impacts to the community's health. This study aimed to determine the level of risk to mercury at Krueng Kalee community through health risk assessment approach.

\section{METHOD}

This study is a descriptive observational research with cross sectional design and field study method of Environmental Health Risk Analysis (ARKL). Purposive sampling was used to select the study sample. The sample size for this study was calculated using one-proportion formula. Samples of objects in this study were $8 \mathrm{dug}$ wells used as a source of drinking water. While the samples of this study are 35 people who use well water as a source of drinking water. This study using univariate analysis which is used to describe variables by presenting the frequency distribution table.

Risk assessments contain some or all of the following four steps:

- Hazard identification: The determination of whether a particular chemical is or is not causally linked to particular health effects.

- Dose-response assessment: The determination of the relation between the magnitude of exposure and the probability of occurrence of the health effects in question.

- Exposure assessment: The determination of the extent of human exposure before or after application of regulatory controls.

- Risk characterization: The description of the nature and often the magnitude of human risk, including attendant uncertainty.

\section{RESULT}

\section{A. Hazard Identification}

Krueng Kalee Village is one of the gold processing areas in South Aceh Regency. Gold processing by amalgamation using amounts of mercury uncontrolled. The waste product from the amalgamation process is thrown away directly to the open dug holes. It makes the well water as the source of drinking water for the community is contaminated by seepage of waste containing mercury. Therefore, it is necessary to do the hazard identification for mercury and calculation of risk quotient for the community around gold processing site.

Table 1 shows that the lowest age of respondents was 4 years and the highest age is 70 years. Six (6) subjects of this study were children (under 10 years old) and the questions will be answered by the mother. Most of the respondents were male $(54,3 \%)$ and the rest were female $(45,7 \%)$. As many as $20 \%$ of respondents are at high education level and $80 \%$ have low education. There were $54.3 \%$ of respondents as employees and $45.7 \%$ were unemployments.

TABLE I

CHARACTERISTICS OF RESPONDENTS

\begin{tabular}{|l|l|}
\hline Variable & n $(\%)$ \\
\hline Age, Median (Min-Max) & $35(4-71)$ \\
\hline Sex & $19(54,3)$ \\
Male & $16(45,7)$ \\
Female & \\
\hline Education & $7(20,0)$ \\
High & $28(80,0)$ \\
Low & $19(54,3)$ \\
\hline Occupation & $16(45,7)$ \\
Working & \\
Not Working &
\end{tabular}

\section{B. Dose-Response Assessment}

Dose-response assessment or toxicity assessment aims to estimate the potential for selected chemicals to cause adverse effects in exposed populations and to provide an estimate of the relationship between the extent of exposure and the increased likelihood of adverse effects. The two principal indices of toxicity of dose-response are known as cancer potency slope factor (CSF) and reference dose (RfD).

The dose of mercury response was obtained from Integrated Risk Information System (IRIS) EPA. EPA has derived an oral RfD of $0,0001 \mathrm{mg} / \mathrm{kg} /$ day for mercury.

\section{Exposure Assessment}

According to regulatory of Health Minister No 492/MENKES/PER/IV/2010 about drinking water quality requirements, the maximum mercury concentration in well water is $0,001 \mathrm{mg} / \mathrm{l}$. The result showed that $37,5 \%$ well water is eligible and $62,5 \%$ is not eligible.

The mercury concentration on well water samples that have been examined showed that the mean mercury concentration of $0.0032 \mathrm{mg} / \mathrm{L}$ and standard deviation of $0.002 \mathrm{mg} / \mathrm{L}$ with the lowest concentration of $0.0008 \mathrm{mg} / \mathrm{L}$ and the highest concentration of $0.007 \mathrm{mg} / \mathrm{L}$. 
TABLE II

MERCURY LEVELS IN WELL WATER

\begin{tabular}{|l|l|}
\hline & $\begin{array}{l}\text { Mercury } \\
\text { Concentration } \\
(\mathbf{m g} / \mathbf{L})\end{array}$ \\
\hline Mean & 0,0032 \\
\hline Median & 0,0020 \\
\hline SD & 0,0025 \\
\hline Min & 0,0008 \\
\hline Max & 0,0070 \\
\hline
\end{tabular}

The study result showed that the mean of consumption rate at Krueng Kalee Village is $2.14 \mathrm{~L}$, median $2 \mathrm{~L}$, and standard deviation $0.692 \mathrm{~L}$ with the lowest intake rate of $1 \mathrm{~L}$ and the highest intake rate of $3 \mathrm{~L}$. There are 11 adults $(37,93 \%)$ with consumption rate exceeding EPA default value where the average intake rate for adult is $2 \mathrm{~L}$.

TABLE III

CONSUMPTION RATE OF DRINKING WATER

\begin{tabular}{|l|l|}
\hline & Intake Rate (L) \\
\hline Mean & 2,057 \\
\hline Median & 2 \\
\hline SD & 0,6036 \\
\hline Min & 1 \\
\hline Max & 3 \\
\hline
\end{tabular}

The frequency of exposure in this research using the default value set by US EPA is 350 days/year for adults and children in residential scope.

TABLE IV

EXPOSURE DURATION OF MERCURY

\begin{tabular}{|l|l|}
\hline & $\begin{array}{l}\text { Length of Stay } \\
\text { (year) }\end{array}$ \\
\hline Mean & 28,66 \\
\hline Median & 28 \\
\hline SD & 21,552 \\
\hline Min & 1 \\
\hline Max & 70 \\
\hline
\end{tabular}

Duration time of exposure in this study is calculated by real-time (length of stay) and lifetime. For the duration of the lifetime using the US EPA default value for 30 years. The mean of duration time for mercury exposure in the gold processing community at Krueng Kalee Village is 28,66 years with a median of 28 years, SD 21,552 with a minimum stay of 1 year and the longest 70 years.

TABLE V

ANTHROPOMETRY CALCULATIONS

\begin{tabular}{|l|l|}
\hline & Weight $(\mathbf{k g})$ \\
\hline Mean & 57,2 \\
\hline Median & 64 \\
\hline SD & 18,014 \\
\hline Min & 15 \\
\hline Max & 76 \\
\hline
\end{tabular}

From the measurement results, the average body weight of respondents weighs $57.2 \mathrm{~kg}$, median 64 and SD 18,014 with the lowest body weight of $15 \mathrm{~kg}$ and the highest $76 \mathrm{~kg}$.

Exposure is the process by which an organism comes into contact with a hazard; exposure or access is what bridges the gap between hazard and risk. Exposure assessment aims to recognize risk exposure pathways so that the amount of intake received by individuals in the at-risk population can be calculated.

For exposure assessment, calculating the Intake using the formula :

$$
I_{\mathrm{nk}}=\frac{C \times R \times f_{\mathrm{E}} \times D t}{W_{\mathrm{B}} \times t_{\mathrm{avg}}}
$$

Specification :

$I_{\mathrm{nk}} \quad$ : Intake, total concentration risk agents that enter the human body with a certain body weight each day (mg/kg/day)

C : Concentration, concentration risk agents in food $(\mathrm{mg} / \mathrm{kg})$

$R \quad:$ Rate, the rate of consumption or intake of entering each day (gram/day)

$f_{\mathrm{E}} \quad$ : frequency of Exposure, the length or the number of days of exposure per year (day/year)

Dt : Duration time, the length or the number of years of exposure (30 year for residential default value)

$W_{\mathrm{B}} \quad$ : Weight of Body, weight of population $(\mathrm{kg})$

$t_{\text {avg }}:$ average time, the period of time the average day (Dt $\mathrm{x}$ 365 days/year for non-carcinogenic substances, 70 years x 365 days/year for carcinogenic substances)

From the above formula, then performed calculations of intake obtained results as follows:

TABLE VI

INTAKE VALUE DISTRIBUTION

\begin{tabular}{|l|c|c|c|c|}
\hline $\begin{array}{c}\text { Intake Non } \\
\text { Carcinogenic( } \\
\text { mg/kg/day) }\end{array}$ & Min & Max & Median & SD \\
\hline Real Time & 0,000021 & 0,000336 & 0,000077 & 0,000094 \\
\hline Life Time & 0,000020 & 0,000480 & 0,000070 & 0,000105 \\
\hline
\end{tabular}

For non carcinogenic intake of mercury exposure through well water it is found that the mean real time intake is $0,000077 \mathrm{mg} / \mathrm{kg} /$ day with minimum intake $0,000021 \mathrm{mg} /$ $\mathrm{kg} /$ day and maximum $0.000336 \mathrm{mg} / \mathrm{kg} /$ day.

\section{A. Risk Characterization}

For risk quotient, calculating of non carcinogenic risk was determined based on the US EPA method and it is calculated by the formulation below : 


$$
R Q=\frac{I_{n k}}{R f D}
$$

Specification :

RQ : Risk Quotient, the potential for non cancer effects to occur is assessed by comparing exposure or average intake of hazardous substances with corresponding reference doses

RfD : Reference Dose, an estimate of the daily exposure dose that is likely to be without deleterious effect even if continued exposure occurs over a lifetime

TABLE VII

RISK QUOTIENT VALUE DISTRIBUTION

\begin{tabular}{|l|c|c|}
\hline \multicolumn{1}{|c|}{ RQ } & n & \% \\
\hline Real Time & & \\
RQ $\leq 1$ & 22 & 62,86 \\
RQ $>1$ & 13 & 37,14 \\
\hline Life Time & & \\
RQ $\leq 1$ & 28 & 80 \\
RQ $>1$ & 7 & 20 \\
\hline
\end{tabular}

From the results of calculations performed on 35 respondents found that for risk quotient with the real time exposure, as many as $37.14 \%$ of respondents are at risk for exposure to mercury exposure.

\section{DISCUSSION}

After testing the mercury levels in the community well water in Krueng Kalee Village, it was found that as many as 5 out of 8 well water samples in the laboratory exceeded the Permenkes standard 492 of 2010, maximum mercury concentration in drinking water is $0.001 \mathrm{mg} / \mathrm{L}$. The researchers conducted a public health risk analysis using environmental health risk assessment method. The higher levels of mercury concentration in drinking water will increase the health risks that will be received by people who consume them.

The entry of mercury into the bodies of living organisms is primarily through food, because almost $90 \%$ of heavy metals or toxic substances enter the body through food materials [12].

The clinical presentation of an individual exposed to mercury depends upon the dose, the length of, and form of exposure. Acute toxicity is more commonly associated with the inhalation of elemental mercury or ingestion of inorganic mercury. Chronic toxicity is more common from exposure to organic mercury. Irrespective of the chemical form of mercury present, the kidneys and the central nervous system are the two primary target organs of toxicity. All mercury compounds concentrate in the kidney to some extent [13].

Mercury concentrations that exceed the maximum limit set by the Ministry of Health has an effect on the value of RQ. From 13 respondents with RQ> 1, consuming drinking water with a concentration of $0.002 \mathrm{mg} / \mathrm{L} ; 0.003 \mathrm{mg} / \mathrm{L}$; and 0.007 $\mathrm{mg} / \mathrm{L}$. There were as many as 2 child subjects with RQ> 1 values exposed to high concentrations of mercury in drinking water.
The mean intake rate of Krueng Kalee community is as much as $2 \mathrm{~L}$, the more consumption of water contaminated with mercury will further increase public health risks.

The results showed that the mean of intake (non cancer) real time mercury at $0.00011 \mathrm{mg} / \mathrm{kg} /$ day when compared with the EPA reference dose of mercury in water $(0.0001 \mathrm{mg} /$ $\mathrm{kg}$ / day then obtained a real time RQ value of 1.1 (RQ> 1).

If the exposure or intake is less than corresponding RfD (RQ less than 1), the risks are not considered to pose a threat to public health, including sensitive subgroups. If the exposure level of a subtance exceeds the corresponding RfD (if the hazard quotient exceeds 1), there may be concern for potential non cancer effects. In general, the greater the value of the risk quotient above 1, the greater is the level of concern. However, risk quotient does not represent a statistical probability of an effect occurring [14].

This means that mercury exposure to the total number of respondents in the gold processing area in Krueng Kalee Village has shown a health risk (non-carcinogenic) and so does the default value for the duration of exposure (life time).

It can be mitigated by risk management by changing the rate of drinking water intake to the safe level. The safe level intake for 13 risky respondents is as follows:

TABLE VIII

RATE OF CONSUMPTION FOR RISK MANAGEMENT

\begin{tabular}{|c|c|c|c|c|}
\hline $\begin{array}{l}\text { Wb } \\
(\mathrm{kg})\end{array}$ & $\mathrm{C}(\mathrm{mg} / \mathrm{L})$ & $\begin{array}{c}\text { Dt } \\
\text { (Year) }\end{array}$ & $\mathbf{R}(\mathrm{L})$ & $\begin{array}{c}\text { Safe Level of } \\
\text { Consumption Rate } \\
\text { (L) }\end{array}$ \\
\hline 20 & 0,007 & 10 & 1 & 0,298 \\
\hline 25 & 0,007 & 8 & 1 & 0,372 \\
\hline 47 & 0,002 & 38 & 3 & 2,451 \\
\hline 55 & 0,007 & 28 & 2,5 & 0,819 \\
\hline 55 & 0,002 & 34 & 3 & 2,868 \\
\hline 57 & 0,007 & 60 & 2 & 0,849 \\
\hline 63 & 0,007 & 35 & 2 & 0,938 \\
\hline 65 & 0,003 & 23 & 3 & 2,259 \\
\hline 65 & 0,007 & 28 & 2,5 & 0,968 \\
\hline 65 & 0,007 & 38 & 2,5 & 0,968 \\
\hline 65 & 0,007 & 61 & 2,5 & 0,968 \\
\hline 71 & 0,007 & 1 & 2 & 1,057 \\
\hline 76 & 0,007 & 40 & 2 & 1,132 \\
\hline
\end{tabular}

\section{CONCLUSION}

The mean concentration of mercury in the respondent's well water $(0.0032 \mathrm{mg} / \mathrm{L})$ has exceeded the regulatory of health minister on Water Quality Requirements where the mercury maximum allowable level in drinking water is $0.0001 \mathrm{mg} / \mathrm{L}$.

The calculation of the mean intake of respondents in Krueng Kalee Village and comparing it with the reference dose of EPA is RQ> 1 so it can be concluded that the Krueng Kalee Village community is at risk for health impact due to mercury exposure. This study only takes to account mercury exposure by drinking water consumption.

Based on this research, it is expected to be the source of information for the Public Health Service in South Aceh Regency to formulate programs to control the health risk. One of the program is to recommend a healthy drinking water intake corresponding to the risk management result 


\section{ACKNOWLEDGMENT}

A lot of thank to my lecturers for all of their support and guidance in helping me to finish my task. Special appreciation to the Health Office in South Aceh Regency and Krueng Kalee community for giving me permission and great co-operations as long as I've been there and my gratitude to all of the participants and people who were involved in this study.

\section{REFERENCES}

[1] Agency for Toxic Substances and Disease Registry, Toxicological Profile for Mercury, US Department of Health and Human Services, 1999.

[2] D.T. Sembel, Environmental Toxicology; The Impact of Pollution from Various Chemicals in Everyday Life, Andi Offset, Yogyakarta, 2015.

D.T. Sembel, Toksikologi Lingkungan: Dampak Pencemaran dari Berbagai Bahan Kimia dalam Kehidupan Sehari-hari, Andi Offset, Yogyakarta, 2015.

[3] Y. Diantoro, GOLD; Investment and Processing, Gramedia Pustaka Utama, Jakarta, 2010.

Y. Diantoro, EMAS; Investasi dan Pengolahannya, Gramedia Pustaka Utama, Jakarta, 2010.

[4] United Nations Environment Programme, Global Mercury Assessment 2013; Sources, Emissions, Releases and Environmental Transport, UNEP Chemicals Branch. Geneva, 2013.

[5] UNEP, Guidance for Identifying Populations at Risk from Mercury Exposure, UNEP DTIE Chemicals Branch and WHO Department of Food Safety, Zoonoses and Foodborne Diseases, Geneva, 2008.

[6] J. S. Slamet, Environmental Toxicology, Gadjah Mada University Press, 2015.

J. S. Slamet, Toksikologi Lingkungan, Gadjah Mada University Press, 2015.

[7] ATSDR, Public Health Assessment Guidance Manual, US Department of Health and Human Services, 2005, Available : http://www.atsdr.cdc.gov/HAC/PHAManual/

[8] WHO, Environmental Health Criteria 27: Guidelines on Studies in Environmental Epidemiology, Geneva, 1983.

[9] S. Obiri, P. O. Yeboah, S. Osae, S. Adu-kumi, S. J. Cobbina, F. A. Armah, B. Ason, E. Antwi, and R. Quansah, "Human Health Risk Assessment of Artisanal Miners Exposed to Toxic Chemicals in Water and Sediments in the Prestea Huni Valley District of Ghana, “ International Journal of Environmental Research and Public Health. Vol. $13,2015$.

[10] A. Mangampe, A. Daud and A. B. Birawida "Risk Analysis of Mercury $(\mathrm{Hg})$ in Mackerel and Blood Cockle on Society Coastal Region Makassar City, “ MPH Thesis. Hasanuddin University, Makassar, 2014.

A. Mangampe, A. Daud and A. B. Birawida "Analisis Risiko dalam Ikan Gembung dan Kerang Darah pada Masyarakat di Pesisir Kota Makassar, "MPH Thesis. Universitas Hasanuddin, Makassar, 2014.

[11] Sofia and A. H. Husodo. "Mercury Contamination in the Environmental Samples and Risk Factors in Inhabitants of the Small Scale Gold Mining Activities Krueng Sabee Aceh Province," Human and Environment Journal, vol. 23, no. 3, 310 - 318, Sept 2016.

[12] M. R. Nakoe, Y. Ardian, A. Ruhardi, F. Dwinugroho, R. Yudhastuti, L. Sulistyorini, R. Azizah and D. Indriani, "Risk Assessment Exposure of Mercury $(\mathrm{Hg})$ at People who Consuming Nila Fish (Oreochromis niloticus) from Limboto Lake of Gorontalo Province, "Research Journal of Pharmaceutical, Biological and Chemical Science, page no. 1420, sep - oct 2014.

[13] L. A. Broussard, C. A. Hammet-Stabler, R. E. Winecker and J. D. Ropero-Miller, "The Toxicology of Mercury," Laboratory Medicine, no. 8, vol. 33. Aug 2002.

[14] R. V. Kolluru, S. M. Bartel, R. M. Pitblado and R. S. Stricoff, Risk Assessment and Management Handbook for Environmental, Health and Safety Professional, McGraw-Hill, New York, 1996. 